\title{
Distribution and ecology of the lichen Fellhanera gyrophorica in the Pojezierze Olsztyńskie Lakeland and its status in Poland
}

\author{
Dariusz Kubiak* \\ Department of Mycology, Warmia and Mazury University in Olsztyn, Oczapowskiego 1a, 10-957 Olsztyn, Poland
}

\section{Abstract}

The study presents recent data on the distribution of Fellhanera gyrophorica (Pilocarpaceae, Ascomycota) in Poland, a rare lichen with a crustose, usually sterile thallus. Both previous and new localities of the species are presented with data on its ecology and general distribution. Furthermore, this paper provides detailed results on floristic investigations of the species in the forest areas of the Pojezierze Olsztyńskie Lakeland (northern Poland). Fertile specimens of F. gyrophorica have been observed in Poland for the second time and in the world - for the third time. Also, a new substrate for this species has been found: Acer platanoides. In addition, Carpinus betulus and Populus tremula were also found to be the species' substrates in Poland. Based on this study and previous reports, F. gyrophorica seems to be a relatively common species in north-eastern Poland.

Keywords: inconspicuous crustose lichens, new localities, old-growth forest

\section{Introduction}

Crustose lichens constitute the majority of lichens in the world and are usually dominant component of the local lichen biota. However, it is a very poorly studied group. During the last few years, the degree of knowledge on the crustose lichens and their habitats has increased significantly in Poland. Penetration of areas and habitats, previously neglected by lichenologists, as well as better methods of taxa identification, e.g., more common usage of thin layer chromatography (TLC), allowed to discover many species previously unknown in Poland [1-10] and new localities for taxa already known to exist in Poland [11-20]. However, current knowledge about the majority of species, especially those in which the ascomata are formed sporadically or not at all, is still insufficient. Besides their distribution, the ecology of these lichens and their sensibility to anthropopressure are very poorly studied. Insufficient knowledge about the species hinders proper determination of the extent of the threat to the species. Therefore, it is necessary to conduct further research to recognize the exact status and ecology of crustose lichens. This article presents information on Fellhanera gyrophorica Sérus. Coppins, Diederich \& Scheidegger, a species occurring in several localities in the central and north-eastern parts of Poland. The main objective of this

\footnotetext{
*Email: darkub@uwm.edu.pl

This is an Open Access digital version of the article distributed under the terms of the Creative Commons Attribution 3.0 License (creativecommons.org/licenses/by/3.0/), which permits redistribution, commercial and non-commercial, provided that the article is properly cited.
}

study was to determine the prevalence and habitat preferences of this lichen in a selected mesoregion in which this species had not been found before.

\section{Material and methods}

Results presented in this paper summarize a research into the species diversity of lichens conducted in the years 20062011 on the area of selected forest complexes of the Pojezierze Olsztyńskie Lakeland $\left(3817 \mathrm{~km}^{2}\right)$, covering the best preserved (the oldest) fragments of meso- and eutrophic deciduous forests - lowland beech forests Galio-Fagetum, sub-Atlantic oak-hornbeam forests Stellario-Carpinetum and subcontinental oak-linden-hornbeam forests Tilio-Carpinetum. The study encompassed both areas of nature reserves as well as managed forests. A detailed list of explored areas and applied methods of inventory was provided in Tab. 1. In the case of most of the research areas, the field investigation was conducted with the line transects method. On the area of Las Warmiński Nature Reserve, the survey were conducted at 60 research sites with a constant area of $0.04 \mathrm{ha}$, each time determined in the central part of the analyzed forest community. All potentially suitable substrata were searched for lichens, however, particular attention was paid to epiphytes. A detailed list of recognized taxa on each study site was prepared. In the case of trees colonized by $F$. gyroforica, quantitative proportions (the cover) of species on a tree trunk were determined as well. Species difficult to identify in the field were collected for further routine examinations in the laboratory. The TLC method, following Orange et al. [21], was applied for identification of the most sterile taxa (solvent C). Comparative studies were conducted in the Puszcza Białowieska Forest within the framework of a project in order to fill in the gaps on the diversity of lichens and lichenicolous 
Tab. 1 Description of the study areas.

\begin{tabular}{|c|c|c|c|c|}
\hline \multicolumn{2}{|l|}{ Area } & Size (ha) & Dominated forest community & Data collection methods \\
\hline \multicolumn{2}{|c|}{ Kamienna Góra Nature Reserve } & 95.14 & $\begin{array}{l}\text { lowland beech forest Galio odorati-Fagetum with a broad ecological } \\
\text { amplitude, acidiophilous beech forest Luzulo pilosae-Fagetum and sub- }\end{array}$ & line transects method \\
\hline \multicolumn{2}{|c|}{ Las Warmiński Nature Reserve } & 1803.15 & $\begin{array}{l}\text { Atlantic oak-hornbeam forest Stellario holosteae-Carpinetum } \\
\text { oak-linden-hornbeam forest Tilio-Carpinetum (52.6\%), continental oak- } \\
\text { pine forest Querco roboris-Pinetum }(22.3 \%) \text {, fresh pine-spruce forest }\end{array}$ & floristic relevés metod \\
\hline \multicolumn{2}{|c|}{ Dęby Napiwodzkie Nature Reserve } & 37.11 & $\begin{array}{l}\text { sub-Atlantic oak-hornbeam forest, degenerated forms of streamside alder- } \\
\text { ash forest and oak-pine forest }\end{array}$ & line transects method \\
\hline \multicolumn{2}{|c|}{ Koniuszanka II Nature Reserve } & 64.55 & oak-linden-hornbeam forest, streamside alder and alder-ash forest, & line transects method \\
\hline \multicolumn{2}{|c|}{ Źródła rzeki Łyny Nature Reserve } & 120.5 & $\begin{array}{l}\text { spring communities, streamside alder forests, degenerative forms of oak- } \\
\qquad \text { linden-hornbeam forest }\end{array}$ & line transects method \\
\hline \multirow[t]{2}{*}{ Kudypy FD } & forest arboretum & $15.69^{1}\left(0.5^{2}\right)$ & $\begin{array}{l}\text { oak-linden-hornbeam forest with broad ecological amplitude, pine and } \\
\text { oak old-growth stands }\end{array}$ & line transects method \\
\hline & fs No. 259 & 28.2 & & \\
\hline \multirow[t]{2}{*}{ Olsztyn FD } & fs No. 290 & 25.66 & & line transects method \\
\hline & fs No. 243 & 38.48 & & \\
\hline \multirow[t]{2}{*}{ Wichrowo FD } & fs No. 402 & 38.14 & & line transects method \\
\hline & fs No. 403 & 25.55 & & \\
\hline Wipsowo & fs No. 36 & 19.03 & & line transects method \\
\hline FD & fs No. 37 & 21.12 & & \\
\hline
\end{tabular}

${ }^{1}$ Total area. ${ }^{2}$ Excluded part of natural forest communities.

fungi of this forest complex (see [22]).

Distribution of localities of $F$. gyropohorica in Poland (Fig. 1) was presented in the ATPOL grid square ([23]; modified by Cieśliński and Fałtynowicz [24]). The nomenclature of lichens follows Fałtynowicz [25] and Diederich et al. [26], except for Bacidia hemipolia f. pallida [5] and Rinodina degeliana [27]. Names of plant communities were accepted after Matuszkiewicz [28] and names of physical-geographical mesoregions after Kondracki [29]. The collected material (34 specimens of F. gyrophorica and several hundred specimens of other species) was deposited in the Herbarium of the Department of Mycology, the University of Warmia and Mazury in Olsztyn (OLTC-L). The following abbreviations are used: FD - forest district, fs - forest section, NP - national park, NR - nature reserve, ! - specimen with apothecia.

\section{Results}

Fellhanera gyrophorica Sérus., Coppins, Diederich \& Scheidegger [30].

Fellhanera gyrophorica (Pilocarpaceae, Ascomycota) was recently described by Sérusiaux et al. [30], based on the collection originating from several countries of Central Europe. Specimens of this lichen were previously reported in several publications as "Fellhanera sp." (see [31]). Probably the oldest known specimen of F. gyrophorica comes from Poland, from the 1950s. This specimen was discovered during the revision of the herbarium of Professor T. Sulma, which comes from the Wysoczyzna Elbląska High Plain [32]. F. gyrophorica was described as a species new to science, based only on sterile specimens with pycnidia [30]. A year later, fertile thalli with apothecia were discovered in the Puszcza Białowieska Forest in Poland [33]. This discovery proved the accuracy of the former diagnosis. F. gyrophorica usually lacks ascomata but is well characterized by the thallus, which is rather thick and produces numerous and distinct pycnidia (Fig. 2). The detailed description of F. gyrophorica can be found in studies by Sérusiaux et al. [30] and Sparrius [33].

\section{Ecology}

In Poland, according to the previous study, F. gyrophorica was reported from the bark of Alnus glutinosa, Fagus

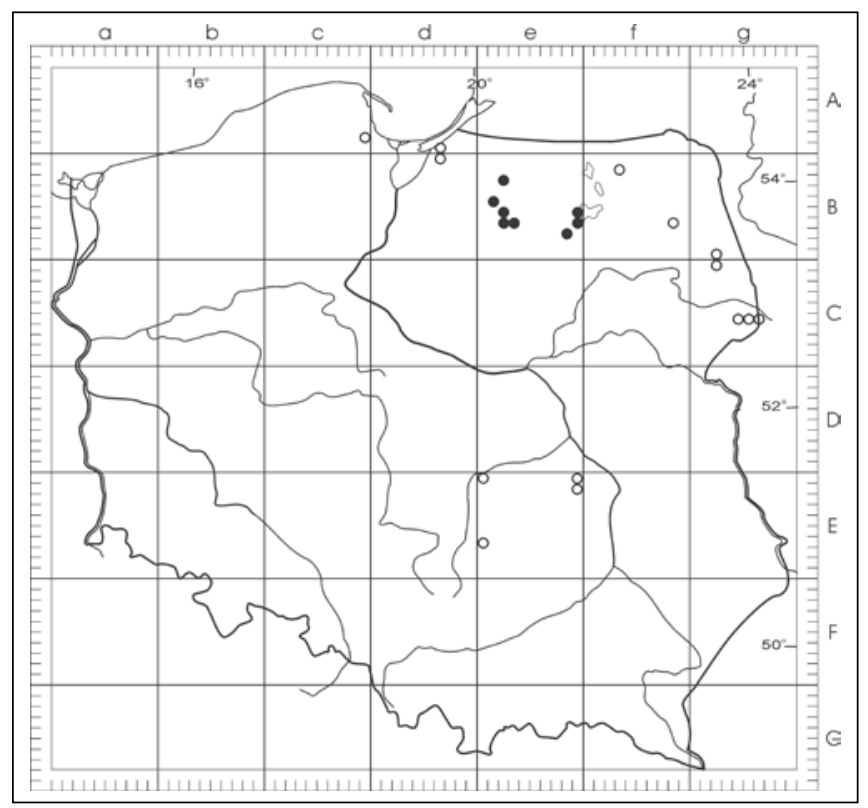

Fig. 1 Distribution of Fellhanera gyrophorica in Poland, in the ATPOL grid square system. White circles - known localities; black circles - new localities. 


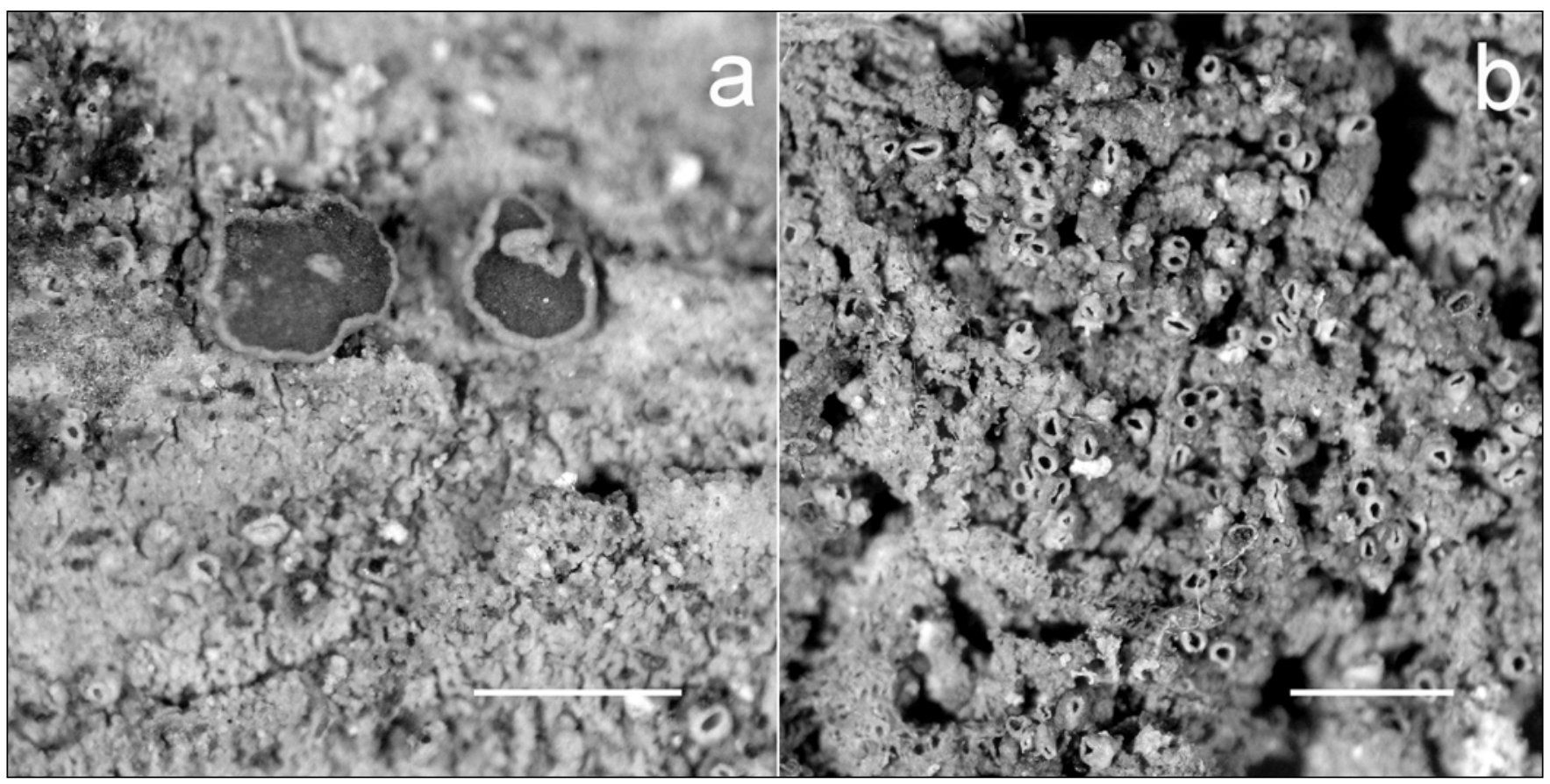

Fig. 2 Fellhanera gyrophorica. a Thallus with apothecia and pycnidia (OLTC-L 3123). b Thallus with pycnidia (OLTC-L 3182). Scale bars: 1 mm.

sylvatica, Fraxinus excelsior, Quercus robur and Tilia cordata $[11,20,32,34-36]$. The only known data on the occurrence of this taxa on wood comes also from Poland [35]. At newly discovered localities in the Pojezierze Olsztyńskie Lakeland, the species has been recorded on Acer platanoides, Carpinus betulus, Populus tremula, Quercus robur and Tilia cordata. The author observed it on Carpinus betulus and Quercus robur in the Puszcza Białowieska Forest, where previously it was reported only from Alnus glutinosa and Fraxinus excelsior [37].

F. gyrophorica grows in Poland mostly in humid, meso- and eutrophic broadleaved forests; in oak-linden-hornbeam and alder swamp forests - in the north-eastern and central part of the country and in beech forests - in northern parts. In the Las Warmiński Nature Reserve, Fellhanera gyrophorica occurs in mature forest stands, at least 129 years old (Tab. 2). The average age of these forest stands was more than 182 years. Although F. gyrophorica preferred the oldest tree stands, the age of trees, on which it was observed, was highly differentiated (Tab. 3). The lichen grew on barks of young trees, for example 50 years old hornbeams; however, it was also observed on 250 years old oaks. From the phytosociological perspective, Fellhanera gyrophorica grows in the best preserved patches of subcontinental oak-linden-hornbeam forests, representing the fresh (TilioCarpinetum typicium) and dry (T.-C. calamagrostietosum) communities. In the reserve, the species forms moderately differentiated epiphytic communities, which include several lichen species (Tab. 3). Nine to twenty two accompanying species were observed on a single tree. However, considering the diverse age and kind of settled phorophytes, the total number of accompanying species is relatively high and amounts to 68 . The most differentiated communities were recorded on old hornbeams. Among accompanying species, a large number of rare and threatened lichens was observed (Tab. 3).

Outside Poland, Fellhanera gyrophorica was recorded on the bark of several phorophytes, both deciduous (Alnus glutinosa, Carpinus betulus, Fagus sylvatica, Fraxinus excelsior, Populus tremula, Quercus robur) and coniferous (Abies alba, Picea abies) [30,35,38-41]. The species mostly forms epiphytic communities, which are rich in species; however, only a few accompanying species were recorded on younger trees and trees overgrown by bryophytes [30]. Within the distribution range, the lichen grows in well preserved, rather shady and humid deciduous and mixed forests, at low elevations [30,42].

\section{Distribution in Poland}

In Poland Fellhanera gyrophorica was recorded for the first time by Sérusiaux et al. [30], based on specimens from the Puszcza Borecka Forest provided by Dr. A. Zalewska (see also [34]). Its localities were later discovered by Czyżewska et al. [11,37,43], Sparrius [33,35] and Czarnota [44], also in the north-eastern part of the country. In Gdańsk Pomerania, the lichen was found by Kukwa [45], as well as Szymczyk and Kukwa [32]. Recently F. gyrophorica was also reported from central Poland by Cieśliński [46], Motiejūnaitė and Czyżewska [36] and Łubek [20]. In the Pojezierze Olsztyńskie Lakeland, as many as 25 new localities of this species were discovered (Fig. 1), 20 of which were located in the Las Warmiński Nature Reserve, two in the Wichrowo Forest Division and one in the Kamienna Góra Nature Reserve, the Olsztyn Forest Division and the Kudypy Forest Division (the forest Arboretum). The conducted studies also confirmed the previous reports regarding the fact that this is a frequently occurring lichen in the Puszcza Białowieska Forest, especially in the Białowieża National Park.

\section{World distribution}

Fellhanera gyrophorica occurs only in Central Europe, where it has a subcontinental distribution. The species is known from Austria, Belarus, Estonia, Lithuania, Luxembourg, Poland, Slovakia, Switzerland and Ukraine [30,40,42,47].

\section{Specimens examined}

[Be22] - Pojezierze Olsztyńskie Lakeland, Wichrowo FD, fs. No. $239,54^{\circ} 02^{\prime} 04.2^{\prime \prime} \mathrm{N} / 20^{\circ} 23^{\prime} 36.3^{\prime \prime} 9$, oak-hornbeam forest, on oak, 2010.05.22, leg. D. Kubiak (OLTC L-3414), ibid., fs No. 218 , oak-hornbeam forest, $54^{\circ} 02^{\prime} 23.9^{\prime \prime} \mathrm{N} / 20^{\circ} 23^{\prime} 50.3^{\prime \prime} \mathrm{E}$, 
Tab. 2 Lichenological value of forest stands (each with an area of 0.04 ha) with Fellhanera gyrophorica in the Las Warmiński Nature Reserve.

No. of locality

Forest community Age of dominated
stand
No. of lichen
species
No. of red listed species No. of protected
species
No. of species

- indicators of

lowland old-

growth forests

\begin{tabular}{|c|c|c|c|c|c|c|}
\hline $8(707 b)$ & T.-C. typicum & 155 & 42 & 12 & 5 & 4 \\
\hline $10(708 c)$ & T.-C. typicum & 155 & 36 & 11 & 1 & 4 \\
\hline $18(329 \mathrm{i})$ & T.-C. typicum & 131 & 38 & 12 & 4 & 3 \\
\hline $29(705 a)$ & T.-C. typicum & 221 & 63 & 20 & 11 & 8 \\
\hline 47 (297c) & T.-C. typicum & 191 & 68 & 23 & 9 & 10 \\
\hline $58(656 b)$ & T.-C. typicum & 215 & 50 & 21 & 8 & 9 \\
\hline $61(688 c)$ & T.-C. typicum & 205 & 48 & 17 & 6 & 6 \\
\hline $37(729 c)$ & T.-C. mercurialetosum & 220 & 55 & 22 & 4 & 8 \\
\hline $7(707 b)$ & T.-C. calamagrostietosum & 155 & 61 & 20 & 9 & 6 \\
\hline $9(706 c)$ & T.-C. calamagrostietosum & 155 & 41 & 10 & 5 & 5 \\
\hline $11(708 c)$ & T.-C. calamagrostietosum & 155 & 53 & 13 & 8 & 4 \\
\hline 15 (461a) & T.-C. calamagrostietosum & 191 & 39 & 13 & 8 & 3 \\
\hline $31(177 g)$ & T.-C. calamagrostietosum & 231 & 67 & 21 & 9 & 6 \\
\hline $48(296 c)$ & T.-C. calamagrostietosum & 185 & 51 & 18 & 9 & 8 \\
\hline 57 (640b) & T.-C. calamagrostietosum & 129 & 38 & 13 & 6 & 6 \\
\hline $59(657 f)$ & T.-C. calamagrostietosum & 215 & 56 & 21 & 10 & 8 \\
\hline $60(689 b)$ & Querco roboris-Pinetum & 205 & 49 & 14 & 6 & 5 \\
\hline $2(103 a)$ & Peucedano-Pinetum & 135 & 44 & 13 & 8 & 2 \\
\hline
\end{tabular}

T.-C. - Tilio-Carpinetum. ${ }^{\star}$ The number of forest section was given in brackets.

on oak, 2010.05.22, leg. D. Kubiak (OLTC L-3415); [Be41] - Pojezierze Olsztyńskie Lakeland, Kamienna Góra NR, beech forest, on oak, 2005.08.01, leg. D. Kubiak (OLTC L-2036); [Be52] - Pojezierze Olsztyńskie Lakeland, Kudypy, forest arboretum, oak-linden-hornbeam forest, on maple, 2006.07.03, leg. D. Kubiak (OLTC L-2154); [Be59] - Kraina Wielkich Jezior Mazurskich Lakeland, Maskulińskie FD, $53^{\circ} 45^{\prime} 47.4^{\prime \prime} \mathrm{N} / 21^{\circ} 30^{\prime} 53.8^{\prime \prime} \mathrm{E}$, fresh oak-linden-hornbeam forest, on oak, 2010.06.30, leg. D. Kubiak (OLTC L-3469); [Be62] - Pojezierze Olsztyńskie Lakeland, Las Warmiński NR, fs No. $705 \mathrm{~d}, 53^{\circ} 38^{\prime} 59.7^{\prime \prime} \mathrm{N} / 20^{\circ} 30^{\prime} 03.1^{\prime \prime} \mathrm{E}$, oak-linden-hornbeam forest, on oak, 2008.05.01, leg. D. Kubiak (OLTC L-3028); ibid., fs No.

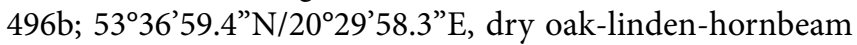
forest, on oak, 2008.05.01, leg. D. Kubiak (OLTC L-3029); ibid., fs No. 496b; 5336'59.4"N/20²9'58.3"E, dry oak-lindenhornbeam forest, on hornbeam, 2008.09.12, leg. D. Kubiak

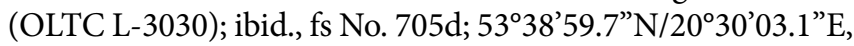
fresh oak-linden-hornbeam forest, on linden, 2008.07.08, leg. D. Kubiak (OLTC L-3031); ibid., fs No. 705a; $53^{\circ} 38^{\prime} 54.5^{\prime \prime} \mathrm{N} / 20^{\circ} 30^{\prime} 24.7^{\prime \prime} \mathrm{E}$, fresh oak-linden-hornbeam forest, on oak, 2008.07.09, leg. D. Kubiak (OLTC L-3032, -3033); ibid., $53^{\circ} 38^{\prime} 53.9^{\prime \prime} \mathrm{N} / 20^{\circ} 30^{\prime} 05.7^{\prime \prime} \mathrm{E}$, fresh oak-linden-hornbeam forest, on oak, 2010.04.12, leg. D. Kubiak (OLTC L-3410); ibid., fs No. 297 c; $53^{\circ} 38^{\prime} 37.3^{\prime \prime} \mathrm{N} / 20^{\circ} 30^{\prime} 22.6^{\prime \prime} \mathrm{E}$, fresh oak-linden-hornbeam forest, on hornbeam, 2009.09.16, leg. D. Kubiak (OLTC L-3115); ibid., fs No. 296c; 533' $49.5^{\prime \prime} \mathrm{N} / 20^{\circ} 30^{\prime} 32.1^{\prime \prime} \mathrm{E}$, dry oak-linden-hornbeam forest, on oak, 2009.09.16, leg. D. Kubiak

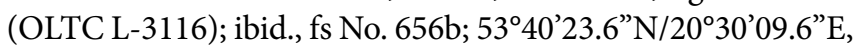
frash oak-linden-hornbeam forest, on maple, 2009.09.22, leg. D. Kubiak (OLTC L-3117); ibid., fs No. 656b, $53^{\circ} 40^{\prime} 23.6^{\prime \prime} \mathrm{N} / 20^{\circ} 30^{\prime} 09.6^{\prime \prime} \mathrm{E}$, fresh oak-linden-hornbeam forest, on hornbeam, 2009.09.22, leg. D. Kubiak (OLTC L-3118); ibid., fs No. 657f, $53^{\circ} 40^{\prime} 14.2^{\prime \prime} \mathrm{N} / 20^{\circ} 29^{\prime} 55.1^{\prime \prime}$, dry oak-linden-hornbeam forest, on oak, 2009.09.22, leg. D. Kubiak (OLTC L-3119); ibid., fs No. 657f, $53^{\circ} 40^{\prime} 14.2^{\prime \prime} \mathrm{N} / 20^{\circ} 29^{\prime} 55.1^{\prime \prime} \mathrm{E}$, dry oak-lindenhornbeam forest, on aspen, 2009.09.22, leg. D. Kubiak (OLTC L-3120); ibid., fs No. $657 f, 53^{\circ} 40^{\prime} 16.1^{\prime \prime} \mathrm{N} / 20^{\circ} 29^{\prime} 50.2^{\prime \prime} \mathrm{E}$, dry oaklinden-hornbeam forest, on oak, 2010.04.17, leg. D. Kubiak

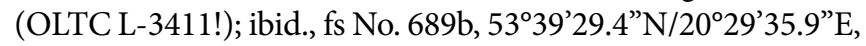
oak-pine forest, on oak, 2009.09.22, leg. D. Kubiak (OLTC L-3121); ibid., fs No. 688c; $53^{\circ} 79^{\prime} 19.5^{\prime \prime} \mathrm{N} / 20^{\circ} 30^{\prime} 18.4^{\prime \prime} \mathrm{E}$, fresh oak-linden-hornbeam forest, on oak, 2009.09.22, leg. D. Kubiak (OLTC L-3122); ibid., fs No. 103a, $53^{\circ} 40^{\prime} 42.9^{\prime \prime} \mathrm{N} / 20^{\circ} 30^{\prime} 43.0^{\prime \prime} \mathrm{E}$, pine-spruce forest, 2009.08.22, leg. D. Kubiak (OLTC L-3178, KRAM); ibid., fs No. 461a; $53^{\circ} 37^{\prime} 31.1^{\prime \prime} \mathrm{N} / 20^{\circ} 30^{\prime} 02.7^{\prime \prime} \mathrm{E}$, dry oak-linden-hornbeam forest, on oak, 2009.08.24, leg. D. Kubiak (OLTC L-3183); ibid., fs No. $708 c, 53^{\circ} 38^{\prime} 52.3^{\prime \prime} \mathrm{N} / 20^{\circ} 28^{\prime} 58.1$ " E, fresh oak-linden-hornbeam forest, on oak, 2009.08.23, leg. D. Kubiak (OLTC L-3184); ibid., fs No. $708 \mathrm{c}, 53^{\circ} 38^{\prime} 44.2^{\prime \prime} \mathrm{N} / 20^{\circ} 29^{\prime} 13.1^{\prime \prime} \mathrm{E}$, dry oak-linden-hornbeam forest, on oak, 2009.08.23, leg. D. Kubiak (OLTC L-3185); ibid., fs No. $706 c$, $53^{\circ} 38^{\prime} 53.9^{\prime \prime} \mathrm{N} / 20^{\circ} 29^{\prime} 44.1^{\prime \prime} \mathrm{E}$, dry oak-lindenhornbeam forest, on oak, 2009.08.23, leg. D. Kubiak (OLTC-L 3186 ); ibid., fs No. $707 \mathrm{~b}, 53^{\circ} 38^{\prime} 44.9^{\prime \prime} \mathrm{N} / 20^{\circ} 29^{\prime} 32.7^{\prime \prime} \mathrm{E}$, fresh oaklinden-hornbeam forest, on linden, 2009.08.23, leg. D. Kubiak (OLTC L-3187); ibid., fs No. 707b, $53^{\circ} 38^{\prime} 44.9^{\prime \prime} \mathrm{N} / 20^{\circ} 29^{\prime} 32.7^{\prime \prime} \mathrm{E}$, fresh oak-linden-hornbeam forest, on linden, 2010.04.17, leg. D. Kubiak (OLTC L-3408); ibid., fs No. 707b, $53^{\circ} 38^{\prime} 59.9^{\prime \prime} \mathrm{N} / 20^{\circ} 29^{\prime} 27.9^{\prime \prime} \mathrm{E}$, dry oak-linden-hornbeam forest, on oak, 2009.08.23, leg. D. Kubiak (OLTC L-3188); ibid., fs No.

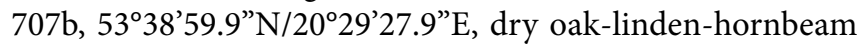
forest, on oak, 2010.04.17, leg. D. Kubiak (OLTC L-3409); 
No. of locality

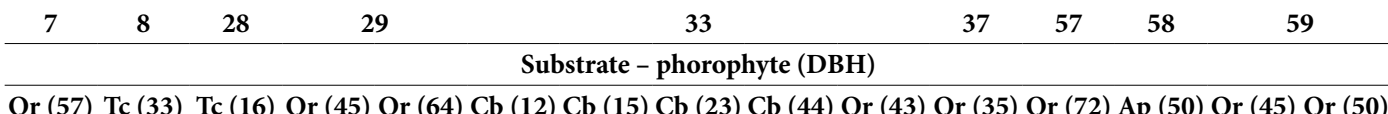

Species

Qr (57) Tc (33) Tc (16) Qr (45) Qr (64) Cb (12) Cb (15) Cb (23) Cb (44) Qr (43) Qr (35) Qr (72) Ap (50) Qr (45) Qr (50)

$\frac{1}{\text { Fellhanera gyrophorica }}$

$\begin{array}{llllllllllllllll}2 & 3 & 4 & 5 & 6 & 8 & 9 & 7 & 10 & 11 & 12 & 13 & 14 & 15 & 16\end{array}$

\section{Lepraria spp.}

Lecanora expallens

Hypogymnia physodes

Micarea prasina s.l.

Phlyctis argena

Chrysothrix candelaris

Pertusaria amara

Arthonia spadicea

Chaenotheca chrysocephala

Ch. ferruginea

Parmelia sulcata

Ramalina farinacea

Arthonia mediella

Biatora efflorescens

Evernia prunastri

Anisomeridium polypori

Coenogonium pineti

Graphis scripta

Lecanora thysanophora

Melanelixia fuliginosa

Opegrapha viridis

Rinodina degeliana

Ropalospora viridis

Buellia griseovirens

Calicium salicinum

Cladonia coniocraea

C. fimbriata

Fuscidea pusilla

Hypcenomyce scalaris

Acrocordia gemmata

Arthonia byssacea

Bacidia biatorina

B. rubella

Chaenotheca furfuracea

Ch. stemonea

Ch. trichialis

Fuscidea arboricola

Lecanora chlarotera

Microcalicium disseminatum

Mycoblastus fucatus

Opegrapha varia

Parmeliopsis ambigua

Amandinea punctata

Arthonia muscigena

A. radiata

A. vinosa

Bacidia arceutina

B. hemipolia f. pallida

Bacidina sulphurella

Biatora vernalis

Calicium adspersum

C. viride

Lecanora argentata

L. conizaeoiodes 


\begin{tabular}{|c|c|c|c|c|c|c|c|c|c|c|c|c|c|c|c|}
\hline 1 & 2 & 3 & 4 & 5 & 6 & 8 & 9 & 7 & 10 & 11 & 12 & 13 & 14 & 15 & 16 \\
\hline L. pulicaris & . & . & . & . & . & 1 & . & . & . & . & . & . & . & . & . \\
\hline Lobaria pulmonaria & . & . & . & . & . & . & . & . & . & . & . & . & . & 1 & . \\
\hline Ochrolechia microstictoides & . & 1 & . & . & . & . & . & . & . & . & . & . & . & . & . \\
\hline O. turneri & . & . & . & . & . & . & . & . & . & . & . & 1 & . & . & . \\
\hline Peltigra praetextata & . & . & . & . & . & . & . & . & . & . & . & . & . & 1 & . \\
\hline Pertusaria coccodes & . & . & . & . & . & . & . & 1 & . & . & . & . & . & . & . \\
\hline P. leioplaca & . & . & . & . & . & . & 1 & . & . & . & . & . & . & . & . \\
\hline P. pupillaris & . & . & . & . & . & . & . & 1 & . & . & . & . & . & . & . \\
\hline Phaeophyscia endophoenicea & . & . & . & . & . & . & . & . & 1 & . & . & . & . & . & . \\
\hline Porina aenea & . & . & . & . & . & . & 1 & . & . & . & . & . & . & . & . \\
\hline Ramalina pollinaria & . & . & . & . & . & . & . & . & . & . & . & 1 & . & . & . \\
\hline Reichlingia leopoldii & . & . & . & . & . & . & . & . & . & . & . & 2 & . & . & . \\
\hline Rinodina efflorescens & . & . & 1 & . & . & . & . & . & . & . & . & . & . & . & . \\
\hline No. of species & 18 & 16 & 13 & 14 & 15 & 9 & 12 & 22 & 19 & 10 & 16 & 17 & 16 & 19 & 18 \\
\hline
\end{tabular}

Cover-abundance scale: 1 - species cover up to $5 \%$ of sample on the three-trunk; 2 - from $5.1 \%$ to $12.5 \% ; 3$ - from $12.6 \%$ to $25.0 \%$; 4 - from $25.1 \%$ to $50.0 \%$; 5 - above 50\%. Ap - Acer platanoides; Cb - Carpinus betulus; DBH - diameter at breast heigh (cm); $\mathrm{Qr}-\mathrm{Quercus} \mathrm{robur;} \mathrm{Tc}-$ Tilia cordata; ! - specimens with apothecia.

ibid., fs No. 496b, 53³6’59.4”N/20²9’58.3”'E, dry oak-lindenhornbeam forest, on hornbeam, 2008.09.12, leg. D. Kubiak (OLTC L-3189!); [Be63] - Pojezierze Olsztyńskie Lakeland, Las Warmiński NR, fs No. 177h, 53³9’47.5"N/20³1'15.5"E, dry oak-linden-hornbeam forest, on hornbeam, 2008.08.14, leg. D. Kubiak (OLTC L-3039); ibid., fs No. $256 \mathrm{~g}, 53^{\circ} 38^{\prime} 53.0^{\prime \prime} \mathrm{N} / 20^{\circ} 30^{\prime} 48.4^{\prime \prime} \mathrm{E}$, oak-pine forest, on oak, 2009.08.24, leg. D. Kubiak (OLTC L-3180); ibid., fs No. 329i, $53^{\circ} 38^{\prime} 04.2^{\prime \prime} \mathrm{N} / 20^{\circ} 31^{\prime} 28.8^{\prime \prime} \mathrm{E}$, fresh oak-linden-hornbeam forest, on linden, 2009.08.24, leg. D. Kubiak (OLTC-L 3181), ibid., fs No. 329i, on mosses growing on hornbeam, 2009.08.24, leg. D. Kubiak (OLTC L-3182); Pojezierze Olsztyńskie Lakeland, Olsztyn FD, fs No. 133, 5341'27.2"N/20³8'25.8"E, oak-lindenhornbeam forest, on oak, 2010.06.03, leg. D. Kubiak (OLTC L-3418); [Be69] - Pojezierze Mrągowskie Lakeland, Krutyński Piecek village, $1 \mathrm{~km}$ on $\mathrm{W}, 53^{\circ} 40^{\prime} 35.2^{\prime \prime} \mathrm{N} / 21^{\circ} 26^{\prime} 18.0^{\prime \prime} \mathrm{E}$, oaklinden-hornbeam forest, on oak, 2010.06.23, leg. D. Kubiak (OLTC L-3470); [Be78] - Równina Mazurska Plain, Pupy NR, fs No. 211, 533'02.0"N/21²1'10.0"E, fresh oak-linden-hornbeam forest with old beeches, on oak, 2011.06.04, leg. D. Kubiak (OLTC L-3473); [Cg55] - Równina Bielska Plain, Białowieża NP, Mogiłki, fs No. 399, 5243’22.7"N/2351'50.6"E, fresh oaklinden-hornbeam forest, on oak, 2006.05.10, leg. D. Kubiak (OLTC L-3110!); ibid., on linden, 2006.05.10, leg. D. Kubiak (OLTC L-3123!); ibid., fs No. 370, 5243’22.6"N/2351'22.0"E, fresh oak-linden-hornbeam forest, on hornbeam, 2006.05.10, leg. D. Kubiak (OLTC L-3124!); ibid., fs No. 340c, on oak, 2006.05.12, leg. D. Kubiak (OLTC L-3125).

\section{Discussion and conclusions}

The inventory revealed 25 new localities of Fellhanera gyrophorica. This is the highest density of the known localities of the species within its occurrence range, documented by collected specimens. Thus, north-eastern Poland and Lithuania are the most important centres of this species' distribution (see [39]).
A relatively high number of newly discovered localities of F. gyrophorica in the Pojezierze Olsztyńskie Lakeland probably results from the choice of the inventory method. The study revealed that the method of floristic relevés - a detailed comprehensive study on a relatively small area, is the most effective in the conservation assessment of inconspicuous lichens with relatively well known ecological requirements (see [48]).

F. gyrophorica has been found in almost all analyzed objects but its frequent occurrence in the Las Warmiński Nature Reserve is worth mentioning. The study has revealed that F. gyrophorica is a relatively common lichen there. The Las Warmiński Nature Reserve protects the largest and best-preserved patches of natural forests occurring in the Pojezierze Olsztyńskie Lakeland. Nearly all the forest communities occurring at the border of north-eastern and central Poland are protected there. The largest area of the reserve is covered by oak-linden-hornbeam forests with a different age structure and high average age of tree stands, which is rarely observed in Poland in forests with such a large area [49]. It should be mentioned that the Las Warmiński Nature Reserve is one of the largest among all analyzed areas and, in contrast to the others, is located within the dense forest complex of Puszcza Nidzicka Forest, which is one of the largest forest complexes in Poland [50].

The presented results seem to confirm the correct rank of the lichen F. gyrophorica recognized as an indicator of lowland old-growth forest in Poland [51]. The species has a similar status in Lithuania, where it was observed only in forests with a long ecological continuity $[38,52]$. One of the features of oldgrowth forests, beside their age and location in vast and dense complexes, is high diversity of cryptogamic plants and fungi [51]. It seems that the majority of newly discovered localities of F. gyrophorica in the Pojezierze Olsztyńskie Lakeland, especially in the Las Warmiński Nature Reserve, fulfill the criterion. Although the lichen biota of the reserve is not fully known yet, it could be considered as rich and diversified [49]. It includes at least 218 taxa that have been discovered thus far. It allows to classify this object within the biocentre group of lichen diversity, not only in the Puszcza Nidzicka Forest, but 
also in the whole country $[43,51]$. Moreover, the lichen biota of the reserve is characterized by a significant number of other species, which demonstrate a particular relationship with oldgrowth forests [49,51]. Against this background, patches of forest communities with F. gyrophorica in the reserve constituted the richest lichen habitats in this area (Tab. 2). As many as 144 lichen species were recorded on 20 analysed sites (with the total area of $0.8 \mathrm{ha}$ ). Thirty six to sixty eight taxa were observed in particular patches - on average over 50 . The biota includes a significant number of threatened (62 species) and protected lichens (19 species) in Poland. At particular sites, 11 to 23 red-listed, and 1 to 11 protected species were recorded. At each site, the presence of lichens - indicators of lowland old-growth forests was also observed in the quantity of 2 to 10 (24 taxa in total). Thus, F. gyrophorica can be accepted as the indicator species, distinguishing the areas with the highest diversity and richness of lichens and probably other organisms.

The study has shown that in the Pojezierze Olsztyńskie Lakeland, the age of the youngest tree stands with F. gyrophorica is usually higher than the clear-cutting age accepted by the national methodology for forest cultivation. This situation creates very unfavorable conditions for the growth of this species in managed forests. Probably for this reason, the main sites of this lichen's occurrence are now national parks, nature reserves and other protected areas, which preserve deciduous old-growth forests of natural character.

The occurrence of F. gyrophorica thalli with apothecia, rarely observed within the species range, is noteworthy. Besides the Polish part of the Puszcza Białowieska Forest [33], the fertile material of this species is known only in Lithuania [38].

It is difficult to assess why the species was previously so rarely reported, particularly within the well explored areas, such as the Puszcza Białowieska Forest (see [53]). One of the reasons could be the fact that the species was spreading rapidly during the last two decades, but most likely it was overlooked in the field or confused with other lichens. $B$. sulphurella (Samp.) Hauck et Wirth (syn. Bacidia sulphurella Samp., Bacidina arnoldiana auct.) is a similar species which very often occurs with pycnidia only $[54,55]$. B. sulphurella can be found in habitats and substrates similar to those of $F$. gyrophorica, but presumably it has a wider ecological range. In the Las Warmiński Nature Reserve, B. sulphurella occurs more rarely than F. gyrophorica and it was documented only at 16 sites. In seven cases both species were observed at one site only, and only in one case they occurred on the same tree (Tab. 3).

Based on the obtained data, it could be assumed that further research will result in a discovery of new localities of F. gyrophorica, especially in north-eastern Poland. New localities of this lichen could be discovered in large forest complexes, e.g., the Puszcza Augustowska Forest and the Puszcza Romincka Forest, where the species has not been found yet [34].

Although regionally $F$. gyrophorica is a relatively common species, since permanent anthropogenic transformations of natural forest environments (also those in protected areas), however it seems relevant to continue with this species' rank as near threatened (NT) in Poland [56].

\section{Acknowledgments}

The author is grateful to the anonymous reviewer for suggestions on the manuscript. The study was partly supported by the Polish Ministry of Sciences and Higher Education (grant
No. N N304 203737 for the years 2009-2011).

\section{References}

1. Czarnota P, Kukwa M. Some sorediate lichens and lichenicolous fungi new to Poland. Graphis Scr. 2004;15:24-32.

2. Czarnota P, Kukwa M. Rinodina griseosoralifera, a lichen species new to Western Carpathians. Acta Mycol. 2007;42(2):287-290.

3. Sliwa L, Tønsberg T. The first record of Fuscidea pusilla (Lichenes, Fuscideaceae) for Poland. Fragm Flor Geobot. 1995;40(2):781-784.

4. Wilk K, Flakus A. Four species of Caloplaca (Teloschistaceae, lichenized Ascomycota) new to Poland. Mycotaxon. 2006;96:61-71.

5. Czarnota P, Coppins BJ. Contribution the knowledge of rare Bacidia s. 1. (Lecanorales, lichenized Ascomycetes) from Central Europe including a new, pallid forma of Bacidia hemipolia. Nova Hedw. 2007;85(3-4):503-513.

6. Kukwa M, Kubiak D. Six sorediate crustose lichens new to Poland. Mycotaxon. 2007;102:155-164.

7. Czarnota P. Japewia tornoensis and further localities of J. subaurifera found in the Carpathians. Acta Mycol. 2009;44(2):259-264.

8. Flakus A, Kukwa M. Additions to the biota of lichenized fungi of Poland. Acta Mycol. 2009;44(2):249-257.

9. Łubek A. Jamesiella anastomosans, a lichen species new to Poland. Polish Bot J. 2009;54(1):125-127.

10. Czarnota P, Flakus A, Printzen C. Lecanora flavoleprosa (Lecanoraceae, lichenized Ascomycota) found in the Carpathians. Biologia. 2009;64:1066-1069. http://dx.doi. org/10.2478/s11756-009-0180-x

11. Czyżewska K, Motiejūnaitė J, Cieśliński S. New and noteworthy species of lichens and allied fungi from northeastern Poland. Acta Mycol. 2005;40(2):277-291.

12. Kukwa M. Nowe stanowiska rzadkich i interesujących porostów na Pomorzu Gdańskim. Część II. Sorediowane i izydiowane porosty skorupiaste. Acta Bot Cassub. 2005;5:113-125.

13. Kukwa M. Lecanora thysanophora (Lecanoraceae, zlichenizowane Ascomycota) w Polsce. Fragm Flor Geobot. 2005;12(2):385-391.

14. Kukwa M, Szymczyk R. Stanowiska porostu Mycobilimbia epixanthoides (Ascomycota lichenisati) na północy Polski. Fragm Flor Geobot. 2006;13(2):429-432.

15. Czarnota P. Lecidea variegatula (Lecanorales, zlichenizowane Ascomycota) nie jest gatunkiem wymarłym w Polsce. Fragm Flor Geobot. 2007;14(1):175-181.

16. Czarnota P, Kukwa M. Contribution to the knowledge of some poorly known lichens in Poland. I. The genus $A b$ sconditella. Folia Cryptog Estonica. 2008;44:1-7.

17. Czarnota P, Kukwa M. Contribution to the knowledge of some poorly known lichens in Poland. II. The genus Psilolechia. Folia Cryptog Estonica. 2008;44:9-15.

18. Czarnota P, Kukwa M. Contribution to the knowledge of some poorly known lichens in Poland. III. Trapelia corticola and the genus Vezdaea. Folia Cryptog Estonica. 2009;46:25-31.

19. Kubiak D, Zalewska A. Notes on Caloplaca lucifuga (Teloschistales, Ascomycota) in Poland. Acta Mycol. 2009;44(2):239-248.

20. Łubek A. New records of lichens from the Polish uplands. 
Acta Mycol. 2009;44(2):275-282.

21. Orange A, James PW, White FJ. Microchemical methods for the identification of lichens. London: British Lichen Society; 2001.

22. Kukwa M, Schiefelbein U, Czarnota P, Halda J, Kubiak D, Palice Z, et al. Notes on some noteworthy lichens and allied fungi found in the Białowieża Primeval Forest in Poland. Bryonora. 2008;41:1-11.

23. Zając A. Atlas of distribution of vascular plants in Poland (ATPOL). Taxon. 1978;27(5-6):481-484. http://dx.doi. org/10.2307/1219899

24. Cieśliński S, Fałtynowicz W, editors. Note from editors. In: Atlas of the geographical distribution of lichens in Poland. Kraków: W. Szafer Institute of Botany, Polish Academy of Sciences; 1993. p. 7-8.

25. Fałtynowicz W. The lichens, lichenicolous and allied fungi of Poland - an annotated checklist. Kraków: W. Szafer Institute of Botany, Polish Academy of Sciences; 2003.

26. Diederich P, Ertz D, Stapper N, Sérusiaux E, Van den Broeck D, van den Boom P, et al. The lichens and lichenicolous fungi of Belgium, Luxembourg and northern France [Internet]. 2010 [cited 2010 Apr 23]; Available from: http:// www.lichenology.info

27. Coppins BJ. A new corticolous sorediate Rinodina from Swedish Lapland. Lichenologist. 1983;15(02):147-150. http://dx.doi.org/10.1017/S0024282983000225

28. Matuszkiewicz J. Zespoły leśne Polski. Warszawa: Polish Scientific Publishers PWN; 2001.

29. Kondracki J. Geografia regionalna Polski. 2nd ed. Warszawa: Polish Scientific Publishers PWN; 2001.

30. Sérusiaux E, Coppins BJ, Diederich P, Scheidegger C. Fellhanera gyrophorica, a new European species with conspicuous pycnidia. Lichenologist. 2001;33(4):285-289. http:// dx.doi.org/10.1006/lich.2001.0328

31. Diederich P. Les lichens épiphytiques et leurs champignons lichénicoles (macrolichens exceptés) du Luxembourg. Luxembourg: Musee national d'histoire naturelle de Luxembourg; 1989. (Travaux scientifiques du Musée national d'histoire naturelle de Luxembourg; vol 14).

32. Szymczyk R, Kukwa M. Nowe dane do rozmieszczenia porostów Wysoczyzny Elbląskiej z historycznych zbiorów prof. T. Sulmy. Fragm Flor Geobot. 2008;15(2):289-297.

33. Sparrius LB. Discovery of apothecia confirms generic position of Fellhanera gyrophorica. Lichenologist. 2002;34(1):86. http://dx.doi.org/10.1006/lich.2001.0370

34. Cieśliński S. Atlas rozmieszczenia porostów (Lichenes) w Polsce Północno-Wschodniej. Warszawa: Białowieża Geobotanical Station; 2003. (Phytocoenosis - Supplementum Cartographiae Geobotanicae; vol 15 pt 15).

35. Sparrius LB. Contribution to the lichen floras of the Białowieża Forest and the Biebrza Valley (Eastern Poland). Herzogia. 2003;16:155-160.

36. Motiejūnaitè J, Czyżewska K. Additions to the biota of lichens and lichenicolous fungi of Poland with note on Lecania prasinoides in eastern and central Europe. Polish Bot J. 2008;53(2):155-162.

37. Czyżewska K, Motiejūnaitė J, Cieśliński S. Species of lichenized and allied fungi new to Białowieża Large Forest (NE Poland). Acta Mycol. 2001;36(1):13-19.

38. Motiejūnaitė J, Kukwa M, Czarnota P, Prigodina-Lukošienė I, Himelbrant D, Kuznetsova E, et al. Lichens and allied fungi collected during the 15th symposium of Baltic mycologists and lichenologists in Birštonas, Lithuania. Botanica Lithuanica. 2003;9:109-119.

39. Motiejūnaitè J, Alstrup V, Randlane T, Himelbrant D, Stončius D, Hermansson J, et al. New or noteworthy lichens, lichenicolous and allied fungi from Biržai district, Lithuania. Botanica Lithuanica. 2008;14(1):29-42.

40. Golubkov VV, Kukwa M. A contribution to the lichen biota of Belarus. Acta Mycol. 2006;41(1):155-164.

41. Motiejūnaitè J. Lichens and allied fungi of two regional parks in Vilnius area (Lithuania). Acta Mycol. 2009;44(2):185-199.

42. Motiejūnaitė J, Prigodina-Lukošienè I. Chaentohecopsis rubescens new to Lithuania and Fellhanera gyrophorica new to Estonia. Graphis Scr. 2002;13:43-44.

43. Czyżewska K, Cieśliński S, Motiejūnaitè J, Kolanko K. The Budzisk nature reserve as a biocentre of lichen diversity in the Knyszyńska Large Forest (NE Poland). Acta Mycol. 2002;37(1-2):77-92.

44. Czarnota P. Charakterystyka porostów na powierzchniach monitoringu fitocenoz leśnych. Biuletyn Monitoringu Przyrody. 2004;1(5):25-32.

45. Kukwa M. Nowe stanowiska rzadkich i interesujących porostów na Pomorzu Gdańskim. Część III. Acta Bot Cassub. 2006;6:141-152.

46. Cieśliński S. Stan bioty porostów w wybranych rezerwatach w Puszczy Kozienickiej. Parki Nar Rez Przyr. 2007;26(3):3-21.

47. Pišút I, Lackovičová A, Guttová A, Palice Z. New lichen records from Bukovské vrchy Mts (NE Slovakia). Acta Mycol. 2007;42(2):267-280.

48. Lõhmus P, Lõhmus A. The importance of representative inventories for lichen conservation assessments: the case of Cladonia norvegica and C. parasitica. Lichenologist. 2009;41(1):61-67. http://dx.doi.org/10.1017/ S002428290900807X

49. Hołdyński C, Sawicki J, Dynowski P, Kubiak D, Woźniak M. Inwentaryzacja siedliskowa i florystyczna rezerwatu przyrody Las Warmiński. Olsztyn: Regionalna Dyrekcja Ochrony Środowiska w Olsztynie; 2009.

50. Zaręba R. Puszcze, lasy i bory Polski. Warszawa: Państwowe Wydawnictwo Rolnicze i Leśne; 1981.

51. Czyżewska K, Cieśliński S. Porosty - wskaźniki niżowych lasów puszczańskich w Polsce. Monogr Bot. 2003;91:223-239.

52. Motiejūnaitė J, Czyżewska K, Cieśliński S. Lichens - indicators of old-growth forests in biocentres of Lithuania and north-east Poland. Botanica Lithuanica. 2004;10(1):59-74.

53. Cieśliński S. Wykaz gatunków porostów (grzybów zlichenizowanych) Puszczy Białowieskiej (NE Polska). Parki Nar Rez Przyr. 2010;29(2):3-39.

54. Brand M, Coppins BJ, Van Den Boom PPG. Further data on the lichen genus Bacidia s.l. in the Canary Islands and Western Europe, with descriptions of two new species. Bibl Lichenol. 2009;99.

55. Hauck M, Wirth V. New combinations in Bacidina. Herzogia. 2010;23(1):15-17.

56. Cieśliński S, Czyżewska K, Fabiszewski J. Red list of the lichens in Poland. In: Mirek Z, Zarzycki K, Wojewoda W, Szeląg Z, editors. Red list of plants and fungi in Poland. Kraków: W. Szafer Institute of Botany, Polish Academy of Sciences; 2006. p. 71-89. 